\title{
LEPROSY IN THE GOLD COAST
}

A SHORT REPORT ON ANTI-LEPROSY WORK IN THE Gold COAST WITH SUGGESTIONS FOR ITS FURTHER DEVELOPMENT.

\section{INTRODUCTORY.}

\section{$\mathrm{T}$} HE British Empire Leprosy Relief Association suggested that their Medical Secretary should visit the Gold Coast, and, after studying the leprosy problem there, make suggestions for its further development of antileprosy work. This suggestion was welcomed by Sir Thomas Stanton and by the Honourable the Director of Medical Services. I had an opportunity of discussing my proposed visit with the Director of Medical Services, who was then home on leave, before leaving London. The Acting Director of Medical Services kindly prepared an itinerary and made all arrangements for my tour.

Before visiting the Gold Coast I spent two months in Nigeria, seeing the anti-leprosy work which is being done there and preparing a report on this work with suggestions for a new scheme of development. My experience of antileprosy work has chiefly been in India, where conditions are in many respects different from those in West Africa. I was therefore glad to have an opportunity of studying the disease first in Nigeria, where within the last few years a number of large leper settlements have been formed under whole-time doctors, and a considerable effort is being made to deal with the problem from the Public Health point of view. I have supplied a copy of my Nigeria Report to the Director of Medical Services and shall refer to it in the present report, mentioning it as "N.R." and referring to its sections and paragraphs as in the Report.

\section{Notes on the Leprosy Institutions Visited.}

Accra Leper Camp. Visited on 1st June, 1936, in company with the Acting Director of Medical Services, the Senior Health Officer and the Port Health Officer.

It is situated beside the sea shore about $1 \frac{1}{2}$ miles from the town. It consists of a central two-storied wooden building with an iron roof. The upper storey is at present used as a store, but is available for educated patients when necessary. The lower storey is used as a dispensary and treatment room and provides accommodation for the African Superintendent. The patients are accommodated in wooden huts with corrugated iron roofs, two being housed in each building. The huts are arranged in rows, the accommodation 
for the men being a short distance from that for the women. The camp was originally designed as an infectious diseases camp, but has been used as a leper camp since 1920 .

I examined the patients as far as time permitted and classified them as follows:-

$\begin{array}{cccc} & \text { Male. } & \text { Female. } & \text { Total. } \\ \text { N1. } & 1 & 1 & 2 \\ \text { N2. } & 2 & 3 & 5 \\ \text { N3. } & 6 & 5 & 11 \\ \text { C1. } & 3 & 1 & 4 \\ \text { C2. } & 10 & 9 & 19 \\ \text { C3. } & 12 & 8 & 20 \\ \text { ? } & 2 & - & 2 \\ \text { Total } & 36 & & \end{array}$

Thus 39 , or 61.9 per cent, are highly infectious cases, and 11 , or 17.4 per cent, are deformed and crippled.

I am informed that about one-third of the patients came from Accra and its neighbourhood, about one-third from other parts of the Gold Coast, and the remainder from French Territory and other places outside the Gold Coast. The patients are given three pence to $4 \frac{1}{2}$ pence a day. The cost of maintenance of patients, drugs, etc. is between $£ 360$ and $£ 400$ a year. There is an African Caretaker on the spot and the Port Health Officer visits the camp and carries on treatment. Alepol is the drug chiefly used.

The soil and sanitation are unsuitable for development as a farm colony.

Ho Settlement. I visited this on 2nd and 3rd June, 1936, in company with the Medical Officer of $\mathrm{Ho}$, who in addition to his other duties gives part of his time to the superintendence of the settlement. The patients are lodged in parallel well-spaced rows of huts. The former thatched roofs have been replaced with corrugated iron since they were destroyed by fire last year. The buildings are in rows, on land sloping down to a small stream from which water is available, though insufficient in the dry weather. A well was built near this stream but has turned out unsatisfactory. The camp is not far from the town of Ho, and a proposal has been made to bring water in pipes from the water supply of the town.

There are about 28 acres of land at present, and a proposal has been made to extend the colony as an agricultural farm similar to those in Nigeria; but I understand that an excessive price is asked by the owners for the surrounding 
land. A grant of $£ 1,900$ a year is made by the Government for the maintenance of the colony.

Of the patients 264 were ranged up, grouped according to their villages, for my inspection. I divided them into various geographical groups and also classified them according to the type of disease, as seen in the following table :-

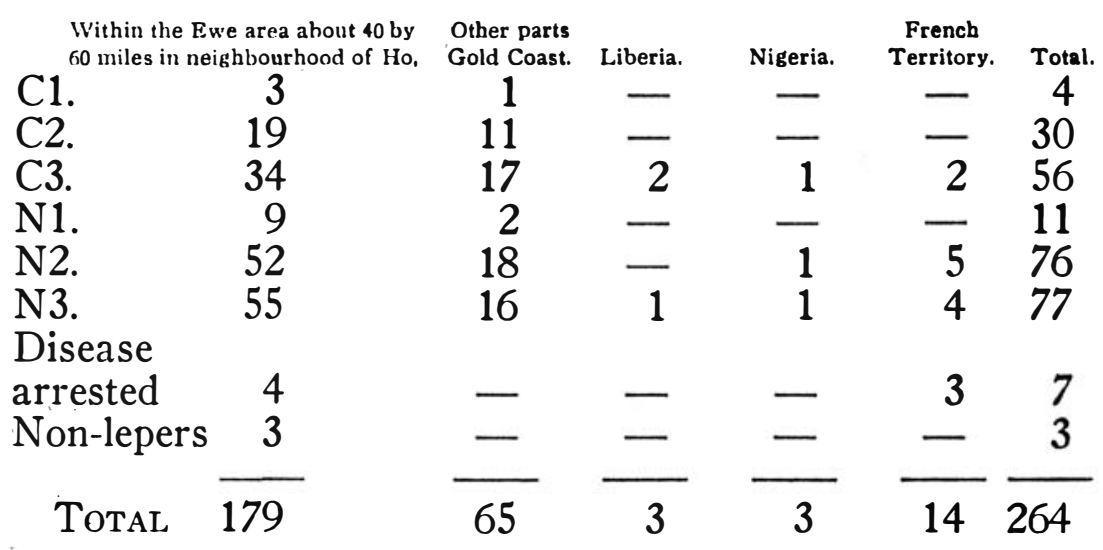

I saw also one non-African case.

Thus about 68 per cent. were from the neighbourhood of Ho and 25 per cent. from more distant parts of the Gold Coast. Some 32.5 per cent. may be counted as highly infectious cases, and about 37.6 per cent. as hopeful cases, and about 30 per cent. crippled cases.

The sanitary system is bucket latrines, which are attended to by non-lepers.

A certain amount of farming is done by the lepers, but only a limited amount of land is available for this purpose.

The leper colony at Itu, as shown in the Nigerian Report, is conducted on an annual grant of about $£ 2,600$, but this includes the salaries of the Medical Officer and the Industrial Officer. So that Ho, with less than 300 patients, costs more than Itu with its 1,500 patients. As pointed out in the Nigerian Report, a colony can be made largely selfsupporting by farming and industries, and it is much more economical to have large settlements with whole-time workers that small settlements with part-time workers.

There are among others three great difficulties in the way of developing the Ho settlement into one like Itu and Uzuakoli, viz. the difficulty in obtaining sufficient land, the great proportion of hopeless cases who have no interest in recovery, and the absence of whole-time European workers.

Yendi Leper Camp. I visited this on 6th June, 1936, in company with the Medical Officer. The care of this camp 
is only one of his many duties. The present camp is in the close vicinity of the general hospital, but a new camp is in course of construction about one mile distant. The construction of the new huts has been carried out at a small cost with the aid of the lepers themselves. There were about 15 cases, of which some six appeared to be highly infectious cases. Most of the patients come from villages to the east, north east and south east, that is from East Dagomba. The patients are given a penny or penny half-penny a day. This they supplement as best they can by farming and in other ways, but the Medical Officer did not consider their diet as satisfactory.

Kumasi Leper Camp. Visited on 7th June, 1936, in company with the Medical Officer of Health. There are 25 cases of leprosy. They are lodged in dormitories in wooden. buildings with corrugated iron roofs lined with wood. They are supplied with food and they have facilities for a little farming in the neighbourhood of the camp. Of the 25, 8 were highly infectious cases. They came from the following districts :-

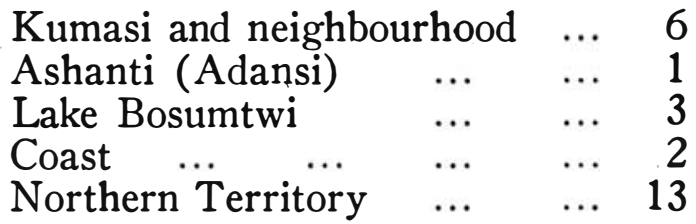

The patients appeared happy and contented. Treatment is given by the Medical Officer of Health.

Lake Bosumtwi. As this is supposed to be a centre of leprosy, I visited it along with the Medical Officer, Bekwai, on 10th June, 1936. We went about 15 miles from Bekwai to Morontus by motor, then about $1 \frac{1}{2}$ miles down to Apewu on the lake. We visited 7 out of the 24 villages on the lake and found 20 cases of leprosy, viz. :

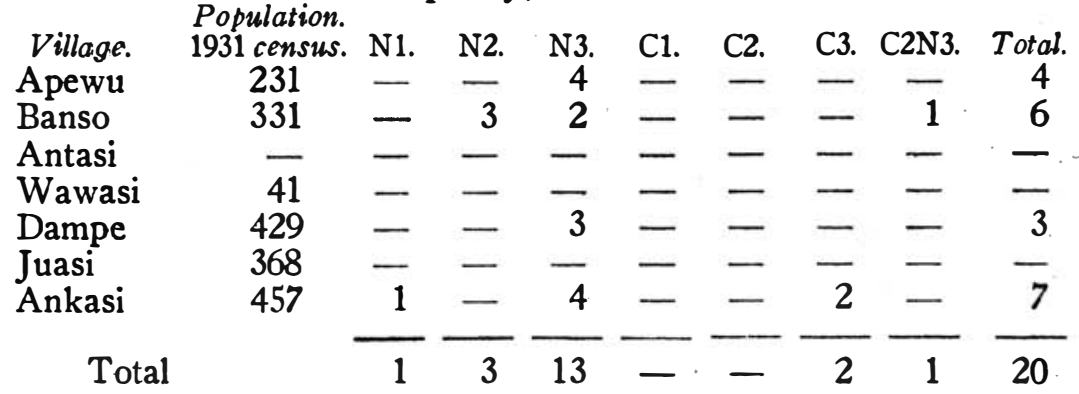

Thus there were 20 cases in 4 out of 7 villages visited, 13 of these being deformed cases in which the infection had almost or entirely died out. 
At Banso the Chief said that there had been 10 cases who attended a treatment centre at Kumasi. But they were all dead now but one. He however, showed us 6 cases. None of these were infectious except the one survival of the clinic = a C2N2 case.

At Juasi the Chief said there had been 10 cases, but they had all died or gone back to their own villages, because, on the advice of the doctor who had previously carried out a survey, the villagers had proposed to isolate them in huts outside the village of Juasi. In all the villages the people looked well nourished and the houses were of a good type and apparently not over-crowded. In only one case was a child living in the same room with an infectious case.

There is abundant fish in the lake, so that the people do not lack for proteins. There is cocoa-farming round the lake, and this should bring in comparative wealth to the villagers. The close proximity to the lake also helps to render the people cleaner than in other places. There is a certain amount of yaws, but not as bad ( $\mathrm{I}$ am informed by the Medical Officer) as in other villages.

The disease of leprosy seems to have been associated with Lake Bosumtwi from ancient times; but it would appear from our investigations and the type of case most prevalent, as far at least as the 7 villages we visited are concerned, that leprosy is dying out now. Apparently people were sent from outside villages to live at the lake, possibly because it is considered sacred. In India lepers are found in large numbers round sacred shrines, because leprosy is supposed to be the result of former sins which must be exculpated by religious observances. Possibly lepers were sent to Lake Bosumtwi for a similar reason, or else in order to get rid of the danger of infection they were sent to this far off wild place.

Possibly the introduction of cocoa-farming has changed the aspect of this region, bringing wealth and increase of population, where formerly there was only dense bush.

The lake is also apparently increasing in size as there are many old trees standing far out in the water, and the people of Dampe told us that their village was formerly situated far out in the present lake. The place is one of great interest and would repay further careful investigation.

\section{Discussion.}

Leprosy may be considered from four points of view, viz. the aesthetic, charitable, medical and public health. According to the first, deformed and disabled lepers are an 
eye-sore in the town, and a place of refuge is therefore created for them to which they can be removed. From the charitable point of view these victims are looked upon as unfortunates and charitably disposed people supply comforts in the form of food, treats, left-off clothing, etc. The medical standpoint is shown when leper's attend hospital and dispensary for treatment, either of the leprosy itself or of its complications and accompanying diseases. Attendance however tends to be irregular, and while a few receive benefit, the majority are but little improved. The public health point of view is that which endeavours to probe down into the causes of leprosy, to study it as it exists in the villages and to devise means which, however long they may take to bear fruit, will in the end deal effectively with the disease and bring about its control.

From the aesthetic and charitable points of view I consider that something is being accomplished in the Gold Coast. From the medical side very little is being done except by a few keen doctors who are distressed at the frequency of the disease and are seeking to do what little they can in addition to their many other pressing duties. From the public health standpoint something is being accomplished by the isolation of some 400 lepers, about one-third of which may be considered as highly infectious cases. But, in the absence of any clear indication of the actual incidence and distribution of leprosy in the country, it is difficult to say to what extent the spread of the disease is likely to be limited by the partial removal of these cases from contact with the public.

\section{Suggestions.}

(1) Need of a Survey. In Nigeria the number of lepers is estimated at 200,000 at least, making an incidence of 1 per cent. on an average. In some places the incidence is much less than this, and in others very much higher.

So far no satisfactory estimate of the incidence of leprosy is available. The 1931 census report shows as much as 4 per cent. in some villages; but these figures are acknowledged by public health workers to be unreliable. Short surveys of very limited extent have been carried out by two medical officers in recent years; but these were not extensive enough to give the necessary data for forming an effective and comprehensive programme.

I consider that the first step necessary is to form a survey party headed by a medical man who has had wide experience of leprosy and who is keen on anti-leprosy work and survey 
work. As assistants he should have four carefully selected Africans of Sanitary Inspector type, who are acquainted with the vernaculars. The head of the party would train his assistants in anti-leprosy work first at the Ho settlement, and later in course of village leprosy surveys. The party would then carry out a series of sample surveys in selected areas, seeking to ascertain such particulars as the following :- the incidence of leprosy; the proportion of the various types of the disease; whether the disease is on the increase or decrease or is stationary; the tribes most affected; predisposing causes; the customs of the people regarding leprosy, such as isolating cases \&c.

I would suggest as locations for the first sample surveys, Ho, Kintampo, Mampong, Bekwai, East Dagombe, Navrongo and Cape Coast or some other suitable area in the coastal zone.

Each survey would last for some 2 or 3 months and cover an area of 50 to 100 square miles. Clinics would be started, as without treatment it has generally been found impossible to win the confidence of the people and make a successful survey. If in any place as the result of the activities of the party large numbers of patients attend, then when the party passes on to its next centre a suitable member of the party might be deputed to continue treatment, extend the survey and by means of propaganda to induce the villagers to isolate their infectious cases. The place in the survey party of the deputed worker would be filled up by another appointment.

The length of time necessary for the carrying out of these surveys is difficult to forecast, but I would suggest two years in the first place, to be followed by extension if justified by results.

The selection of the personel, and especially of the head of the party, is of paramount importance. He should be appointed ad hoc. If no suitable doctor is available locally, a well-trained leprosy doctor might possibly be obtained from India, where this type of work has been in progress for several years.

Several doctors and others have suggested to me that lepers should be forcibly isolated. I would strongly urge the danger of attempting forcible segregation. It has been tried in many places without success as lepers tend to conceal their disease (which in most cases can be easily done), and such attempts at force make subsequent attempts at winning confidence of patients very difficult. Indirect compulsion may however be carefully used through clan chiefs and village headmen. 
(2) Ho Leper Settlement. I consider that if the survey shows a high incidence of leprosy in this district, the present settlement should be enlarged and developed as an agricultural settlement along the lines of the Itu and Uzuakoli settlements in Nigeria. Some 500 acres of land would be necessary; and if this cannot be had at the present site, then a new site should be selected with the requirements mentioned in N.R. V., 3.

I consider that this settlement could best be run by mission doctors (see N.R. V., 1). It would be financed by Government as at present, and have a staff as in N.R. V., 2. It would develop along the lines described in N.R. V., 4, 5, $6,7,8$, emphasis being laid on training and making the settlement a centre for leprosy prevention and general public health work throughout the district. Also the formation of clan or village settlements (N.R. VI.), Infant Welfare Work (N.R. VII.), co-operation with the Educational Authorities, (N.R. VIII.), using leprosy as a key disease (N.R. IX.), training of workers, \&c. (N.R. X.), should be developed as far as possible.

(3) An Ashanti Settlement. The Survey party would soon reveal the need or otherwise for another large agricultural leper settlement in Ashanti, and it would give an indication of the most suitable site.

The present information seems to indicate that there is great need for such a settlement, and that the best site would be somewhere in the neighbourhood of Ejura. It is very important that the settlement be situated in an area of fairly high incidence, so that patients may at first be drawn from these villages and preventive work begun in them on an experimental basis under close supervision from the settlement doctor.

What I have mentioned in connection with Ho regarding the settlement being run by mission doctors, and regarding the site, type of building, work, treatment, training, clan settlements, Infant Welfare, \&c., would apply equally to this settlement.

This settlement would be financed by the central Government.

(4) Northern Territories. There are indications that the incidence of leprosy is very considerable in certain parts of the Northern Territories. There is at present the small leper camp at Yendi, a few out-patients are being treated at Tamale, and there is, I believe, a small leper camp at Navrongo. The work of the survey party suggested would 
reveal the need or otherwise for a first-class settlement. The large proportion of cases from the Northern Territories in the Kumasi camp, the census returns and reports of Medical Officers would seem to indicate that there is considerable need for this. I understand that the Native Administrations in the Northern Territories may be in a better financial position to support such a settlement after a period of three years. The settlement if formed should be (except for finance) on the lines suggested for Ho. Meanwhile I would suggest carrying on and gradually developing the present work.

In connection with the three leper settlements suggested, if these are to be run by suitable missions at the expense of Government or Native Administrations, it would be well to constitute Leprosy Boards, as described in N.R. IV., 1.

(5) Accra and Kumasi and other Camps. I would propose that these be continued as at present in the meantime. That, once Ho and other settlements are developed along the lines suggested, patients be returned from Accra and Kumasi to their corresponding settlements. If the survey in the South seems to justify another settlement, this should be formed. Otherwise the Accra camp might be kept for local or coast cases.

\section{Acknowledgements.}

I wish to thank the Gold Coast Government for help given, and record my gratitude to the Acting Director of Medical Services for kindly arranging my tour, and to him and other medical and health officers for their kind hospitality and the care and trouble they took to place all facilities at my disposal and make my tour successful. 


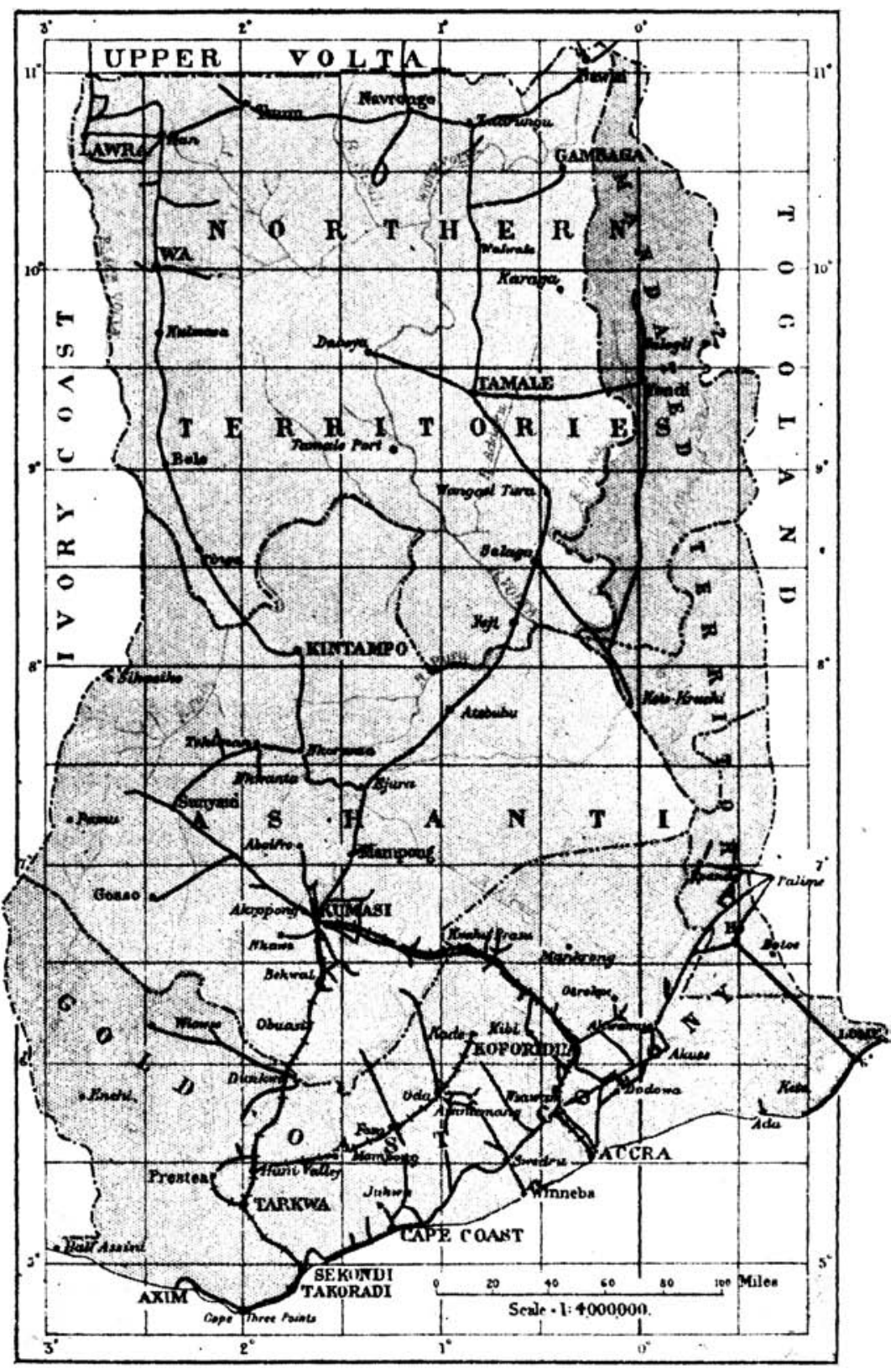

MAP OF THE GOII COAST. 


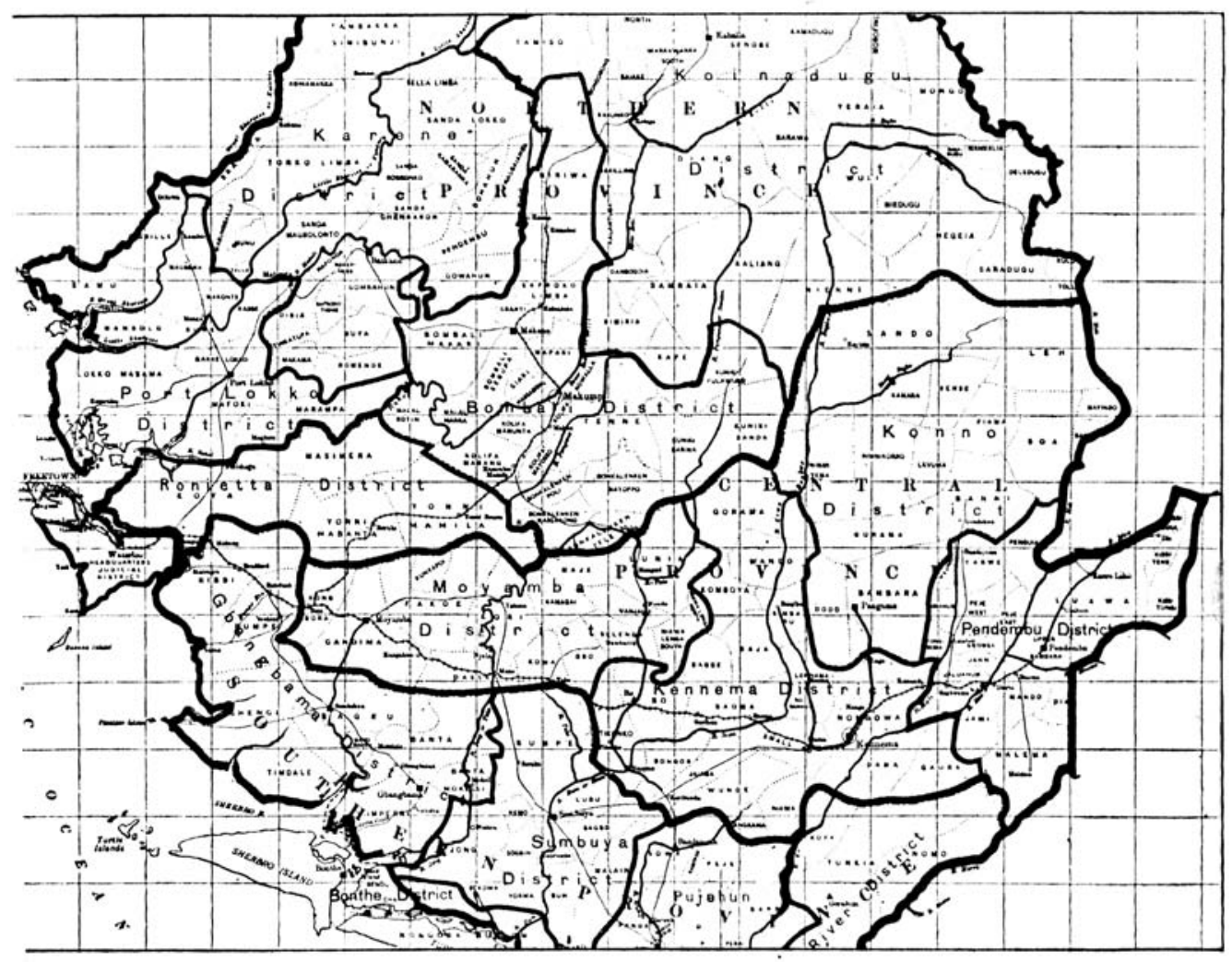

MAP OL SIFRRA IAONL 